\title{
Management of acute myocardial infarction after a blunt chest trauma
}

\author{
Künt gögüs travması sonrası gelişen akut miyokart enfarktüsünün tedavisi
}

\author{
Öner ÖZDOĞAN, ${ }^{1}$ Mustafa KARAÇELİK, ${ }^{2}$ Cenk EKMEKÇI, ${ }^{1}$ Cengiz ÖZBEK ${ }^{2}$
}

Coronary artery dissection is a rare complication after blunt chest trauma. Patients usually present with sudden death and the diagnosis is frequently missed. In this report, we present a case of a 46-year-old with a hyperacute anterior wall myocardial infarction after blunt chest trauma. Diagnostic coronary angiography showed total occlusion of the left anterior descending coronary artery (LAD) starting at the takeoff of the vessel from the left main coronary artery (LMCA). A bare-metal stent was immediately deployed at the proximal LAD and TIMI 3 flow was achieved; however post-procedural images revealed no satisfactory results. A proximal dissection and intraluminal thrombus extending to the LMCA was observed. Because of the proximity of the lesion to the LMCA, re-intervention was considered to be risky and urgent coronary artery bypass grafting (CABG) was planned. Coronary artery stenting is the advised treatment modality for coronary occlusion after blunt chest trauma. However, post-traumatic percutaneous coronary intervention was sometimes considered to be risky because of the anatomic features of the lesion. Timing is cardinal in achieving early reperfusion in the course of myocardial infarction after blunt chest trauma and CABG should be the preferred procedure for initial reperfusion treatment especially in proximal LAD dissections with subsequent thrombus formation leading to total occlusion of the artery.

Key Words: Chest trauma; coronary artery dissection; percutaneous coronary intervention.
Künt göğüs travması sonrası koroner arter diseksiyonu nadir bir komplikasyondur. Hastalar genellikle ani ölüm ile gelirler ve tanı çoğu zaman atlanmaktadır. Bu yazıda künt göğüs travması sonrası hiperakut önyüz miyokart enfarktüsü gelişen 46 yaşında bir olgu sunuldu. Tanısal koroner anjiyografi sol ana koroner arter çıkışından başlayan sol ön inen arterin (LAD) total oklüzyonunu göstermekteydi. Koroner anjiyografi sonrası hızlıca proksimal LAD'ye çıplak stent yerleştirildi ve TIMI 3 akım elde edildi; fakat işlem sonrası görüntüler tatminkâr sonuçlar göstermedi. Proksimal bir diseksiyon ve sol ana koronere yayilan intraluminal trombüs gözlendi. Lezyonun sol ana koroner artere yakınlığından dolayı tekrar girişim riskli bulundu ve acil koroner arter baypas greftleme (CABG) planlandı. Koroner arter stentleme, künt göğüs travması sonrası gelişen koroner tıkanıklıkta tavsiye edilen tedavi yöntemidir. Fakat lezyonun anatomik özelliklerine bağlı olarak perkütan koroner girişim bazen riskli olarak kabul edilmektedir. Künt göğüs travması sonrası miyokart enfarktüsü durumunda erken reperfüzyonun sağlanmasında zamanlama önemlidir ve CABG özellikle damarın total oklüzyonuna yol açan trombüs oluşumu ile birlikte olan proksimal LAD diseksiyonlarında başlangıç reperfüzyon tedavisi için tercih edilen yöntem olmalıdır.

Anahtar Sözcükler: Göğüs travması; koroner arter diseksiyonu; perkutan koroner girişim.
Coronary artery dissection is a rare complication after blunt chest trauma. ${ }^{[1,2]}$ The diagnosis is frequently missed or delayed and since many of the patients present with sudden death, it is an unusual consequence of blunt chest trauma.

In patients who present with chest pain or dyspnea, injury to the heart and coronary vessels should be suspected.

In this report, we present a case of a 46-year-old with a hyperacute anterior wall myocardial infarction (MI) after blunt chest trauma. We discussed the treatment procedures after the coronary artery dissection. 


\section{CASE REPORT}

A 46-year-old, otherwise healthy man was admitted to our hospital with severe sternal and left chest pain. The pain was started 30 minutes after a blunt chest trauma due to a crash by a massive glass block. He described his pain as tightening and it was disproportionately severe to the level of apparent musculoskeletal injury. The patient was in good health and family history was noncontributory. The patient reported no medications or allergies. Initial physical examination revealed no pathological findings; the patient appeared in no apparent distress. Examination upon arrival revealed a heart rate of 98 beats/min, blood pressure at $130 / 80 \mathrm{mmHg}$, respiratory rate at 20 breaths/min, and overt chest wall trauma. Lungs were clear to auscultation. Cardiac examination was normal without murmurs, rubs or gallops. Chest examination revealed external signs of injury to the chest and 6-8 costal fractures on the left side were observed on chest radiography (Fig. 1). Abdominal examination was unremarkable. Initial electrocardiography (ECG) did not reveal any diagnostic abnormalities. During follow up, the patient demonstrated ongoing symptoms and a subsequent ECG featured a hyperacute anterior wall MI (Fig. 2). Transthoracic echocardiography showed moderate hypokinesis of the septum and the anterior wall. Right ventricular and valvular functions appeared normal. No pericardial effusion was observed. A decision was made for an urgent diagnostic coronary angiography.

Diagnostic coronary angiography showed total occlusion of the left anterior descending coronary artery (LAD) starting at the takeoff of the vessel from the left main (Fig. 3). Other coronary arteries were free of coronary artery disease, without significant stenosis. After coronary angiography, a bare-metal stent was immediately deployed at the proximal LAD and TIMI 3 flow was achieved; however post-procedural (Fig. 4a, b) images revealed no satisfactory results. A proximal

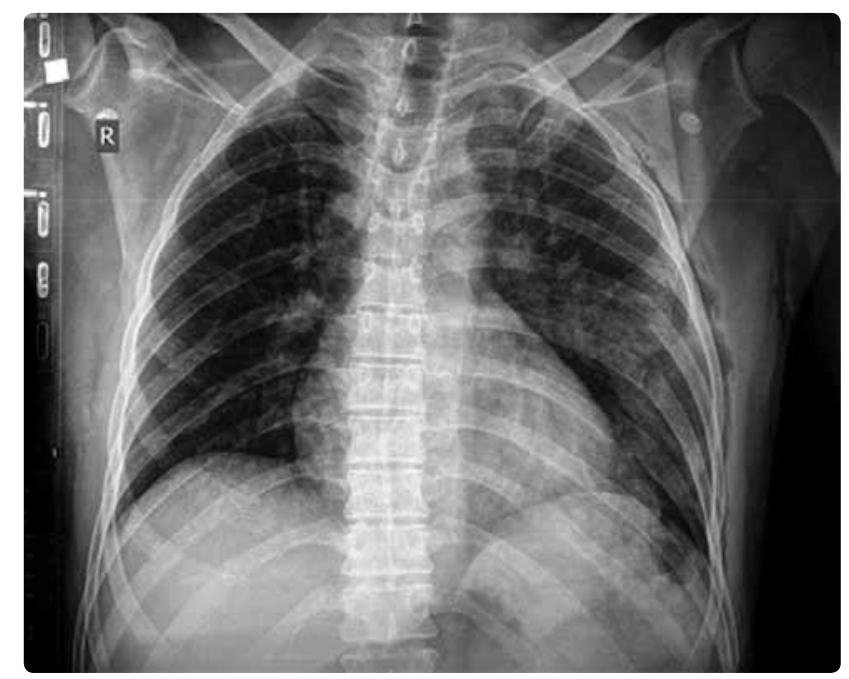

Fig. 1. Left costal fractures at posterior-anterior chest radiography.

dissection and intraluminal thrombus extending to left main coronary artery was observed. Because of the proximity of the lesion to the left main coronary artery, re-intervention was considered to be risky and urgent coronary artery bypass grafting was planned. At surgery he underwent a single bypass graft as follows: left internal mammary artery to LAD. The operative course was uneventful. Respiratory support was required for 42 days after the operation due to the contusion.

\section{DISCUSSION}

In patients who present with chest pain or dyspnea after a blunt chest trauma, injury to the heart and coronary vessels should be suspected. The LAD is involved in the majority of the reported cases ${ }^{[3,4]}$ Intimal tearing caused by shearing forces and the compression of the artery between the heart and the sternum lead to coronary artery dissection. Impairment of the coronary flow by the dissection flap and accompanying intraluminal thrombosis can induce MI as was seen in our patient.

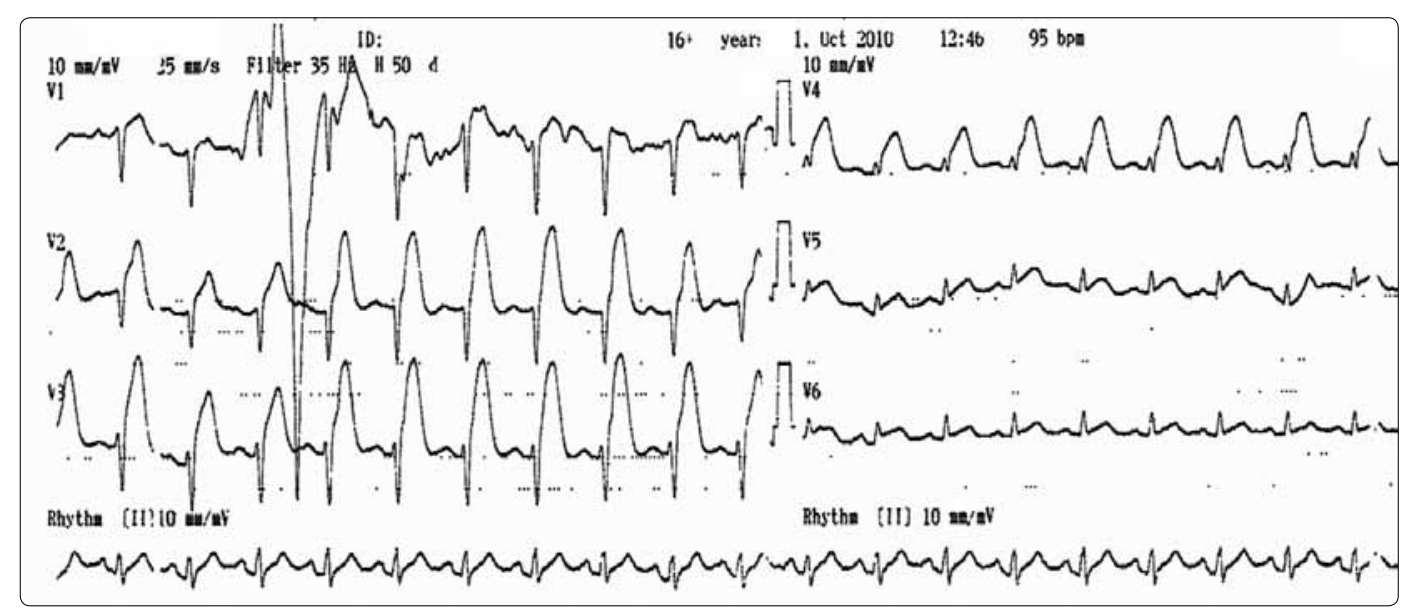

Fig. 2. Electrocardiography after ongoing chest pain. Precordial derivations featuring hyperacute anterior wall infarction. 


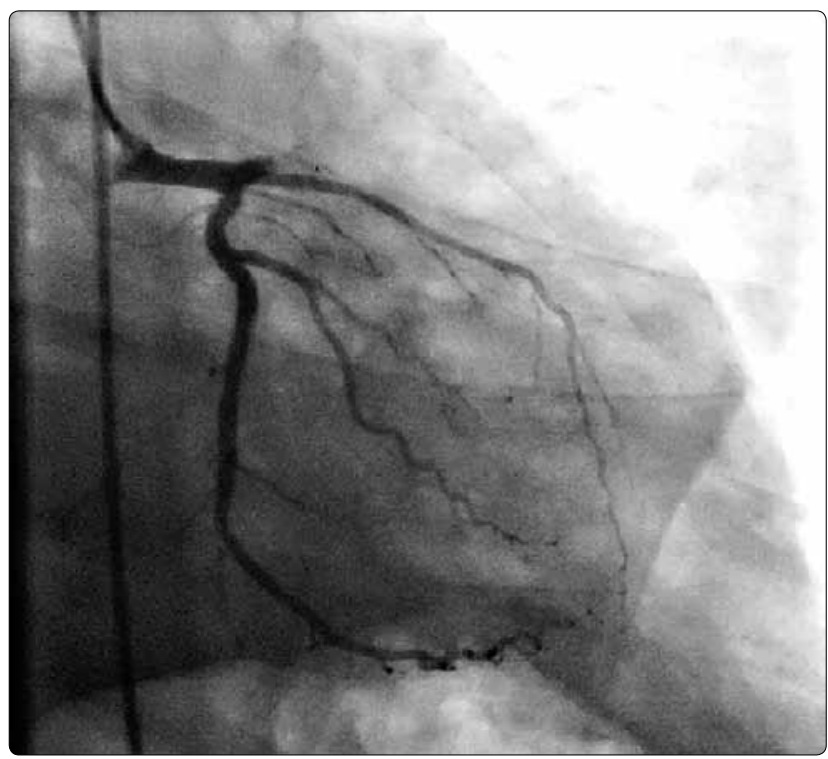

Fig. 3. Right anterior oblique caudal view during the diagnostic coronary angiography showing the proximal total occlusion of left anterior descending artery.

The earliest feature of coronary occlusion is the development of ST/T wave changes observed by ECG. Echocardiography can identify cardiac tamponade, aortic dissection, valvular injury, and wall motion abnormalities.

Delayed revascularization results with increased myocardial damage and sudden death. Furthermore, since it is an acute coronary artery occlusion, ventricular impairment, clinical heart failure, and a worse long-term prognosis should also be taken into account in cases without specific treatments. Treatment pro- cedures include angiography with stenting, thrombolytics, and surgical revascularization. ${ }^{[5-7]}$ However, thrombolytic agents are usually not recommended because of the increased risk of bleeding from associated injuries. On the other hand, since MI could be the result of intimal tear or dissection, thrombolytic therapy may worsen the prognosis itself. Therefore, if coronary artery dissection is suspected, urgent diagnostic cardiac catheterization must be performed. Coronary artery stenting is the advised treatment modality most often reported in previous data. ${ }^{[1]}$ Although it requires aggressive anti-platelet treatment, it is still an important procedure in the setting of acute trauma and is minimally invasive. On the other hand, the use of adjunctive anti-platelet drugs must be individualized depending on the risk of stent thrombosis versus the bleeding threat from associated injuries. Coronary artery bypass surgery is especially recommended in cases with associated valvular disruption.

As reported in our case percutaneous intervention after post-traumatic coronary dissection was sometimes considered to be high risk because of the anatomic features of the lesion. Coronary angioplasty in the proximal LAD usually does not reveal satisfactory results due to the proximity of the lesion to the left main coronary artery and the nature of the lesion. In conclusion, the possibility of severe injury of the heart after blunt chest trauma indicates close follow-up of the patient. The diagnosis should be confirmed by urgent coronary angiography. Although coronary artery dissection is a rare complication after blunt chest trauma, it could lead to MI and sudden death and the diagnosis is frequently missed or delayed. Surgery should

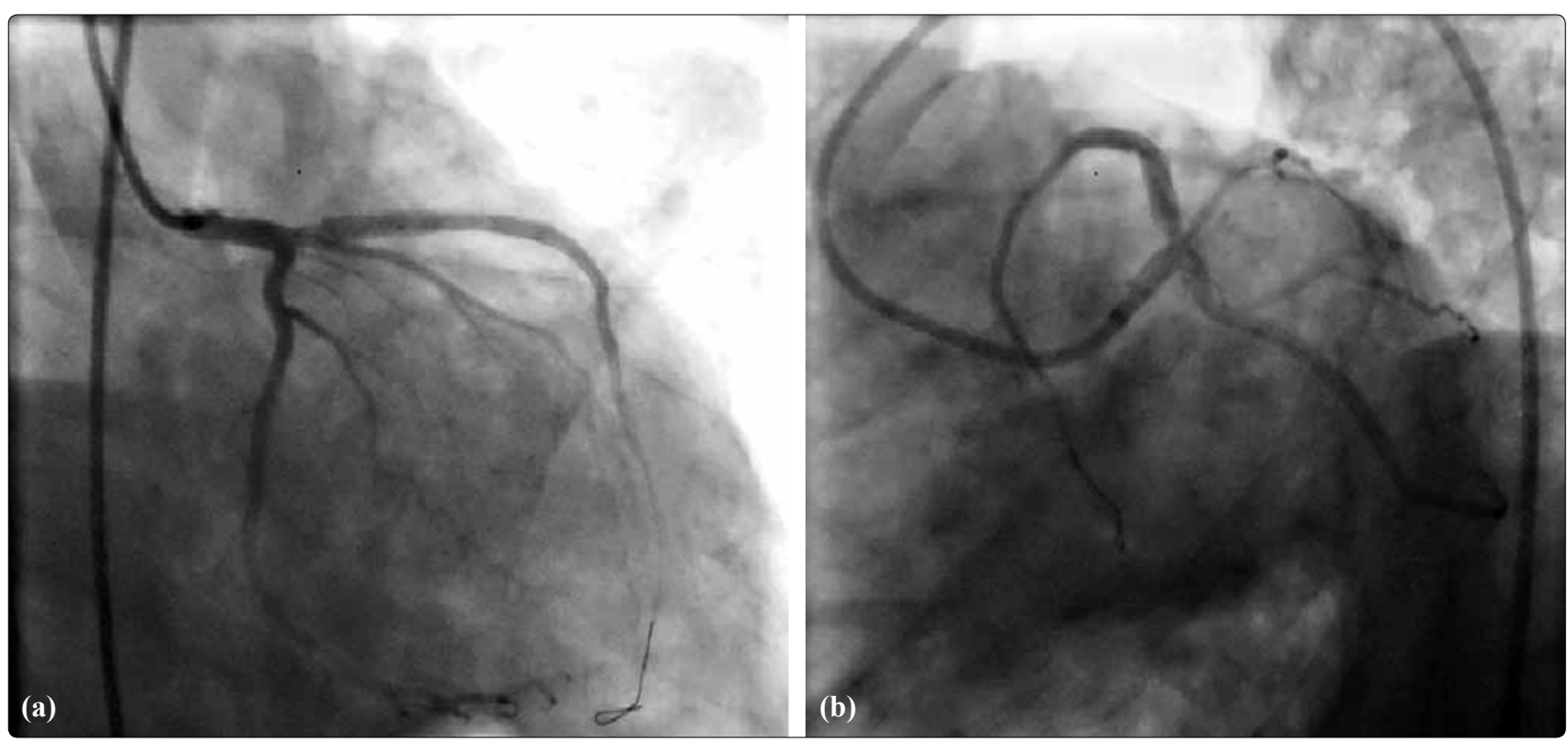

Fig. 4. (a) Right anterior oblique caudal view after bare metal stenting. (b) Left anterior oblique caudal view after coronary bare metal stenting showing intraluminal thrombus and proximal dissection of the left anterior descending artery extending into the left main coronary artery. 
be considered when percutaneous intervention is not appropriate due to the nature of the lesion and when there is associated valvular disruption. As we all know, timing is cardinal in achieving early reperfusion in the course of MI and it could be stated that coronary artery bypass surgery should be the preferred procedure for initial reperfusion treatment especially in proximal LAD dissections with subsequent thrombus formation leading to total occlusion of the artery after blunt chest trauma.

Conflict-of-interest issues regarding the authorship or article: None declared.

\section{REFERENCES}

1. Moreno R, Pérez del Todo J, Nieto M, Alba F, Alfonso F, Garcia-Rubira JC, et al. Primary stenting in acute myocardial infarction secondary to right coronary artery dissection following blunt chest trauma. Usefulness of intracoronary ultrasound. Int J Cardiol 2005;103:209-11.
2. Hobelmann A, Pham JC, Hsu EB. Case of the month: Right coronary artery dissection following sports-related blunt trauma. Emerg Med J 2006;23:580-1.

3. Hazeleger R, van der Wieken R, Slagboom T, Landsaat P. Coronary dissection and occlusion due to sports injury. Circulation 2001;103:1174-5.

4. James MM, Verhofste M, Franklin C, Beilman G, Goldman C. Dissection of the left main coronary artery after blunt thoracic trauma: Case report and literature review. World J Emerg Surg 2010;5:21.

5. Boland J, Limet R, Trotteur G, Legrand V, Kulbertus H. Left main coronary dissection after mild chest trauma. Favorable evolution with fibrinolytic and surgical therapies. Chest 1988;93:213-4.

6. Ginzburg E, Dygert J, Parra-Davila E, Lynn M, Almeida J, Mayor M. Coronary artery stenting for occlusive dissection after blunt chest trauma. J Trauma 1998;45:157-61.

7. Shah P, Dzavik V, Cusimano RJ, Sermer M, Okun N, Ross J. Spontaneous dissection of the left main coronary artery. Can J Cardiol 2004;20:815-8. 